\title{
Selective Self-Presentation Through Video-Mediated Communication: A Study of Hyperpersonal Communication
}

\author{
Palupi \\ Universitas Muhammadiyah Surakarta, Jl. A. Yani Tromol Pos 1, Sukoharjo, Jawa Tengah \\ E-mail: palupi@ums.ac.id
}

\begin{abstract}
The development of the Internet and communication technology has been increasing from time to time. Humans around the globe are connected to digital communication devices. Technology has been growing and changing the way people communicate from text-based computer-mediated communication to video-mediated communication. The study is conducted to determine whether the online users in VMC perform selective self-presentation under conditions when nonverbal cues exist and the interlocutor is not anonymous. This study is qualitative research with a semistructured interview as its method. Findings in this study showed that participants perform selective self-presentation in VMC. By wearing a veil for females or combing hair for males, tiding up the room and table, choosing a certain place, also hiding something from the web camera scope are the ways they present themselves to obtain good impression and avoid bad impression from interlocutors. The findings also discovered that participants perform selective self-presentation to ordinary friends, colleagues, or acquaintances with the same way and the same reason why they perform it when nonverbal cues are presented. However, participants do not perform selective selfpresentation to family and close friends.
\end{abstract}

Keywords: selective self-presentation, VMC, hyperpersonal communication

Abstrak: Perkembangan teknologi Internet dan komunikasi telah meningkat dari waktu ke waktu. Manusia saling terhubung melalui alat komunikasi digital. Teknologi telah tumbuh dan mengubah cara manusia berkomunikasi; dari komunikasi bermediasi komputer berbasis teks menuju komunikasi bermediasi video (VMC). Penelitian ini dilakukan untuk mengetahui apakah pengguna online melakukan presentasi diri selektif pada VMC, yaitu pada kondisi tersedianya isyarat nonverbal dan lawan bicara tidak anonim. Penelitian ini adalah penelitian kualitatif dengan menggunakan wawancara semi struktur sebagai metode pengumpulan data. Temuan dalam penelitian ini menunjukkan bahwa partisipan melakukan presentasi diri selektif dalam VMC. Cara yang mereka lakukan adalah dengan menggunakan kerudung bagi perempuan dan menyisir rambut bagi laki-laki, merapikan ruangan dan meja, memilih tempat tertentu, juga menyembunyikan sesuatu dari lingkup kamera web sebagai bentuk penampilan diri mereka untuk mendapatkan kesan baik dan menghindari kesan buruk dari lawan bicaranya. Temuan penelitian juga menunjukkan bahwa partisipan melakukan presentasi diri selektif kepada teman, kolega, atau kenalan cara dan alasan yang sama dengan mengapa mereka melakukannya dalam kondisi hadirnya isyarat nonverbal. Namun demikian, partisipan tidak melakukan presentasi diri selektif kepada keluarga dan teman dekat.

Kata kunci: presentasi-diri selektif, VMC, komunikasi hiperpersonal 


\section{INTRODUCTION}

The development of computermediated communication led to the emergence ofnew forms of communication. In fact, CMC model is different from face to face communication model. CMC relationship ranges from the impersonal, interpersonal, to hyperpersonal (Walther, 1996). However, since the emergence of Skype in the last decades, CMC has been developing into interactive videomediated communication (VMC). It is interesting to examine how humans interact in interactive VMC. The cost to access the Internet which is relatively inexpensive makes VMC popular among online users; it facilitates them to communicate with each other. VMC provides features which are unavailable in text-based CMC: nonverbal cues presence and channel synchronicity.

Along with the development ofCMC - from text-based to video-based - this new form of communication affects how online users interact with each other. As proposed by Walther (Walther, 1996) that text-based CMC elicited a model which is called hyperpersonal communication, it is likely to question whether this kind of communication model is also relevant to other forms of CMC, specifically videomediated communication.

Several studies on hyperpersonal communication have been conducted within the framework of CMC (e.g. High \& Caplan, 2009; Jiang, Bazarova, \& Hancock, 2011; Joinson, 2001; Okdie, Guadagno, Bernieri, \& Geers, 2011; Walther, 2007; Walther, Slovacek, \& Tidwell, 2001). This model of interaction fosters affection and intimacy between online users which exceeds the relationship on FtF communication. (Walther et al., 2001).

Text-based CMC which has limited nonverbal cues makes receiver interprets the message from the sender excessively, increasing sender's impression which is formed by the receiver (Jiang et al., 2011) Based on SIDE theory, Walther's hyperpersonal model proposes that receiver in CMC has idealized perception about the sender (Walther, 1996). In CMC, sender has more time creating desired self-presentation. Therefore, sender is able to choose what cues will be presented to receiver (Walther, 1992). Asynchronous nature of $\mathrm{CMC}$ and physical cues absence support senders to enhance their self-presentation than in FtF. Technically, CMC offers the ability for its users to increase or select their selfpresentation as messages in CMC can be easily edited; $\mathrm{CMC}$ provides quite a long time to edit the message; as it is separated from the receiver, then the sender's gestures are invisible when composing messages; and the absence of attention to the sender when a message is being processed (Walther, 2007).

Overall, hyperpersonal interaction takes place when receiver has idealized perception of the sender, sender designs enhanced self-presentation, channel provides options and possibilities for user to customize transmitted message, and feedback loops as a result of customized message and selected self-presentation (Walther, 2007).

\section{Critiques of Hyperpersonal Communication}

Inevitably, the combination use of audio and video facilities on the Internet has currently been growing extremely vast in the last decade especially since Skype was launched (Kappas \& Kraemer, 2011). In text-based $\mathrm{CMC}$, the interaction was limited by the presence of nonverbal and visual cues. When the development of the Internet leads to more interactive CMC, hyperpersonal model of communication needs further research whether it is still relevant to new circumstances in CMC.

Regarding real-time form of CMC, weaknesses of hyperpersonal 
theory emerge from one of its key elements, specifically its channel characteristic as nonverbal cues absent, visually anonymous, and asynchronous. Concerning to character of CMC channel which allows users to create messages selectively, there is another idea supports Walther's hyperpersonal communication. Even though CMC now facilitates user with audio and video format, both are only used as an indication of interlocutor presence, not to scan user's physical cues.

Studies in hyperpersonal interaction framework still compared how people communicate through $\mathrm{FtF}$ or $\mathrm{CMC}$ (e.g. Bargh, Mckenna, \& Fitzsimons, 2002; Joinson, 2001; Mckenna, Green, \& Gleason, 2002; Okdie et al., 2011). Moreover, studies on the measurement of communication effectiveness by comparing the text-based $\mathrm{CMC}$ or asynchronous $\mathrm{CMC}$ with synchronous CMC become interesting. Text-based $\mathrm{CMC}$ has indeed been evident to produce closer relationship compare to FtF (Walther, 2011).

Although the development of video-mediated communication has been starting rapidly in recent years, however, it is still limited by what is displayed on the screen. It only scans major in the visual cues, whereas minor changes are ignored (Heath \& Luff, 1991). Moreover, the VMC has distorted visual cues; makes people speak more to cover the shortfall (Sellen, 1995).

\section{Selective Self-Presentation on Computer-Mediated Communication} Visual cues displayed in communication process on online spaces have possibility to be selected and edited before transmitting. Photographs on Facebook page, for example, have in such a way been customized by the account owner to get good impressions in initiating friendships (Wang, Moon, Kwon, Evans, \& Stefanone, 2009). Through photographs, the impression of attraction derived from the facial appearance. Yet, in text-based CMC, impression emerges from receiver's ability to process text in order to get enhanced self-presentation (Walther et al., 2001).

Internet is used to foster relationships with known people and to build unthreatened relationships with unknown people (Mckenna et al., 2002). As hyperpersonal studies of selective selfpresentation, visual anonymity in $\mathrm{CMC}$ facilitates users to disclose themselves on online space easier, but they also have the possibility to overestimate its openness (Whitty \& Joinson, 2009).

\section{Previous Research on Video-Mediated Communication}

Since the launch of Skype, which enables $\mathrm{CMC}$ with the format of audio and video pattern transmission, the process of communication through such media has been blooming especially with almost no cost in accessing it. When the first use of video format in the CMC occurred only in one way communication, now the ability has evolved into what is called videomediated communication, specifically when "interlocutors can make use, at least in part, both when "sending" and "receiving" messages, of the repertoire of nonverbal signals that use the vocalauditory channel (vocal-intonational and paralinguistic aspects of speech) and the visual-kinesic channel (facial expression, gaze direction, gestures, postures, etc.)." (Enrico, Bitti, \& Garotti, 2011).

The presence of video-mediated communication is a breath of fresh air for CMC user due to its format which enables people to communicate more natural (Enrico et al., 2011). As Parkinson and Lea discussed, "immediate personal feedback provided by facial expressions facilitates the development of mutual rapport when attitudes are convergent and may facilitate nonverbal interpersonal 
influence when attitudes are discrepant" (Parkinson \& Lea, 2011, p.100). As a form of simultaneous CMC, VMC makes user feel that the communication conducted is not connected by any medium (Enrico et al., 2011). Nevertheless, the availability of visual information between users in VMC is also a weakness for the relationships itself since the use of the visual information distracts users' focus in performing tasks (Walther, 2011).

In order to distinguish between $\mathrm{CMC}$ and $\mathrm{VMC}$, Parkinson and Lea in their academic writing titled Video-linking Emotions explained some characteristics of VMC (Parkinson \& Lea, 2011). First, users enable to control their appearance in VMC, due to video camera which is used relatively steady in certain position. The distance position as indicator of interaction proximity which usually carried out in $\mathrm{FtF}$ is also unavailable in VMC. Second, communication between users is often conditioned in a framed close-up face. In these circumstances, there is possibility of inhibiting tasks completion where people often avoid facing each other to execute the task (Sommer, in Parkinson \& Lea, 2011). Third, VMC limits transition of gestures as part of nonverbal cues which actually facilitate users to scan next action of their interlocutor. By using non-verbal cues, people try to guess someone's emotions and attitude (Enrico et al., 2011).

Although there are some ideas that VMC is a form of communication which is almost similar to FtF communication, still there are many differences that underlie these two forms of communication. The pattern of audio and video transmitted through the VMC is clearly different from FtF, where the physical signs cannot be directly perceived, for example, the touch or body odor that affects people who directly interacted. Besides, the video camera available does not function properly like human eye as it is able to move up to sender's desire. In VMC, camera position is set in such a way by the user so that the receiver's ability to scan sender's surrounding conditions is very limited. Due to video camera in VMC usually provides a focused image of the face, the nonverbal signs of other parts of body cannot be seen. Users are not able to access other visual cues outside camera frame (Parkinson \& Lea, 2011).

The purpose of this study is to answer questions about selective selfpresentation in VMC. According to hyperpersonal theory, people will show indications of enactment of selective self-presentation in a state of anonymity and nonverbal absence. This study will examine whether it also applies in the video-mediated communication where nonverbal cues exist and interlocutor is not anonymous.

\section{METHOD}

Qualitative method is used to conduct this study. This study aims to assess the answer of how and why people do things based on their experience. Semi-structured interview is used to gain data from participants.

Interviews conducted in a research framework have to be planned and prepared in accordance with research canon. In semi-structured interview, the interviewer has to have more preparation in planning. It also requires a high level of creativity because, at the time of interview conducted, the interviewer requires to break down the interview guidelines that have been made into several separate questions. Another hard part is to analyse the gathered data which spend more time than to analyse structured interview (Wengraf, 2001).

The research involves interviewing by answering several questions to obtain information on how someone interacts and communicates through Skype's online video chat. Twelve interviewees 
involved in this research.

On qualitative research, reliability can be obtained by performing two criteria as described by Moisander and Valtonen (Silverman, 2011) which are to conduct a transparent and detailed explanation of the research strategy and data analysis. The second is to explain in transparent point of view of the theory used in research in order to produce a particular interpretation of the theory.

To improve reliability as Silverman (Silverman, 2011) described, interviewer should record every single interview activity and transcribe the entire contents of the interview rigidly by the interviewer himself/herself. The interviewer is the best person who knows how the interview process is conducted.

Transcription of the interview allows data which was originally a voice recording to be processed and analysed (Poland, 2001). Transcribing semi-structured interview is very timeconsuming. The tone of voice is very influential of the participant's intention. Therefore, the use of punctuation such as commas should be placed squarely in sentences. The emotional and paralinguistic context are also difficult to transcribe. Write a transcription takes very much time (Poland, 2001). In this case, the time spent to transcribe a 30 minutes interview is about 5 hours.

\section{RESULT AND DISCUSSION}

This section examines the data which were obtained from participants. Some common features were noticed and emerged as the result. The data showed how and why online users carry out selective self-presentation through videomediated communication. This section also provides a discussion from the result emerged from the research. It discusses how the results answer the research problems.

The results of this research obtained from the analysed interview data. The result is categorised into several subsections for clarity.

\section{Selective Self-presentation and} Nonverbal Cues Presence

Nonverbal cues that are presented in $\mathrm{VMC}$ are able to display the physical image of its users and their surrounding environment. Nevertheless, nonverbal cues affect how users present themselves in VMC. According to the interview data, there are several ways for users to manage their appearances as follows:

\section{Making Appointment Before Having a VMC}

Sparing particular time is a way for users to prepare themselves before having a video call. By making an appointment, they have more time to organize their schedule, arrange the conversation topic, manage their appearance, and set the surrounding environment where the conversation takes place.

By having more time to manage their appearance, users can select their selfpresentation to gain desired impression from interlocutor. Users can freely set their presentation and hide something that they don't want to show. In addition, knowing what time the video call will be held gives them opportunity to manage their surrounding environment, either to tidy up the place where the device is placed or posit the device on a place where interlocutor cannot see particular area which is deliberately hidden.

Although most of the time participants make an appointment before having a VMC, they are more flexible in certain circumstances. Flexibility applies if the interlocutors are family or close friends who need to discuss urgent topics.

\section{Managing Self-presentation}

Managing self-presentation is how participants set themselves to 
obtain desired impression from their interlocutors in VMC. They differentiate how to present themselves to their family, friend, or colleague. Female and male participants have different way of selecting their self-presentation.

Drawing from interview data, all female participants manage their selfpresentation when they communicate with non-family member. They usually put a head cover when they have a video call with their friends and colleagues. Religious reason becomes their consideration why they manage their appearance in VMC. Because all the female participants are Muslims, they will always cover their head with a veil when they meet people who are not their family, either face to face or through VMC. They want to be seen as practicing Muslim. Thus, they have to make sure there's no part of their body which is forbidden to be shown to non-family member in VMC.

A single women participant explained that she has to wear a veil when she has a video call, besides she will be uncomfortable without veil on her head. The discomfort caused by her self-presentation as a veiled woman that she's been building and managing it all this time. Thus, she assumes that other people will think she's a different figure without it.

However, not all female participants do the same. Two out of six female participants said that they don't need to manage their self-presentation to their female close friends. They think that selecting their self-presentation to their close friends is unimportant. Yet, they will always manage it to non-female family member.

Unlike women, men are more casual in their appearance. From 6 male participants, they only need to straighten their hair if needed. They want to be seen as a neat and clean person. This is also done based on a reason that performing self-presentation in an appropriate way is a form of showing their respect, with an expectation that their interlocutor will do the same too.

\section{Managing Device Position and Surrounding}

In general, users use notebook as a device for having a video call. The advantage of the device used for VMC is its possibility to be placed anywhere according to its users' desire. Hence, users may intentionally show anything that they want to show and hide something that they want to hide. By adjusting the device position, they present selective presentation to get certain impression from their interlocutor.

Overall, all participants arrange to set the notebook place, whether to posit it in a comfortable place or set it to present or hide something. However, the common place to put the notebook is on the table. Besides, they try to present a tidy room and proper to be seen, also hide something that doesn't want to be seen by interlocutor. Thus, the desired impression will be obtained. TS spoke up her thoughts:

I have to tidy up my room. I'm afraid if they [interlocutor] see its messiness, they will think something bad about me ... The laptop has never been moved from there [table]. I don't like to bring my laptop everywhere. There are people who like to take it on the bed. I'm not like that. Bed is only for sleeping. So my laptop is always on the table. (TS, single, female)

In contrast with $\mathrm{TS}$, a single male Master student MS likes to put his notebook suit to where he sits. He explained that he emphasizes his convenience while having a video call rather than being inconvenienced by putting the notebook in certain place.

At least, I'll show only the good part. I don't need to show them everything. I don't want to show the messy part 
... the important thing for me is how convenience its position is. I sometimes take it on my bed, put it on my lap. (MS, single, male)

From his explanation, he always tries to select which part of the room to be shown or hidden to get good impression from whom he talks to. Along with this idea, all participants do similar action like TS or MS on how and why they manage their device position and its surrounding.

\section{Selective Self-presentation and Non- Anonymous Interlocutor}

Although participants are able to see the person whom they talk in VMC, they keep trying to build a good image by making a self-presentation selection. In this category, data analysis will be divided as follows:

(a) Family and Close Friends

Family and close friends are people who aren't worried to think badly about participants' image. When they have a video call with family, they will present themselves as they are. It also applies to their close friends. They consider that family members and close friends know their good and bad side, so the effort to perform selective self-presentation becomes useless.

In the other hand, to respect their interlocutors, participants manage their appearance and their surrounding as necessary, such as wash their face, comb their hair, or tidy up the table or bed. Participants do not consider this as deliberate action to attempt particular image. It is only done to show respect to their interlocutor.

(b) Friends, Colleagues, and Acquaintances

In communicating through VMC to friends, colleagues, and acquaintances, female participants manage themselves at least by covering their head with a veil. For male participants, they will use proper clothing and make sure their face is in a ready position with neat hair. The environment around them will also be tidied up, or if they cannot do so at least they will deliberately hide it from the video frame. Thus, they expect their interlocutor will have a good impression on them. Overall, from participants' narration, it is assumed that selective selfpresentation that they perform to friends, colleagues, and acquaintances has the same degree with face to face interaction

Unlike previous parties as explained before who show their selfpresentation as it is on face to face, a female participant has ever experienced an interview with people she's never met before through VMC. She assumed that by doing a selective self-presentation, she has built a good image so her aim would have been successful. She spent her time to set the device, her surrounding area, also manage herself in order not to leave a bad impression from interviewer.

\section{DISCUSSION}

Having a discussion about VMC means to discuss face to face communication which is limited by the frame (Parkinson \& Lea, 2011). People who are involved in the conversation meet each other through the mediation of computer and the Internet. The form of such mediated-communication is assumed to affect how its users perform their self-presentation as supported by the previous study in the CMC field (see Bargh et al., 2002; High \& Caplan, 2009; Joinson, 2001; McKenna \& Bargh, 1998; Walther, 2007; Wang et al., 2009; Whitty \& Joinson, 2009) as well as VMC (see McKenna \& Bargh, 2000; Parkinson \& Lea, 2011).

\section{Senders and Nonverbal Cues Presence}

In the practice of interactive communication, the sender and receiver are two parties who are actively involved in the conversation. Both of these elements 
function interchangeably. Sometimes sender turns to become receiver, vice versa. Nevertheless, the following subsection will only discuss interviewees' experiences as senders in VMC. For clarity, the term of sender in this section will then be referred to user.

It emerged from the findings that in several conditions in VMC, users deliberately present their good side to obtain certain impression from their interlocutors. This is consistent with Goffman's idea in his book titled Selfpresentation in Everyday Life. He stated that people always try to get desired impression from other people (Goffman, 2008). Previous studies found that this idea applies to face to face interaction and text-based CMC (for example Goffman, 2008; Walther, 2007; Wang et al., 2009). Although the hyperpersonal model of communication examined that on textbased CMC users are not able to access nonverbal cues from their interlocutor, but in certain circumstances, this condition is potentially increasing users' ability to perform selective self-presentation.

$$
\text { Hyperpersonal model of }
$$
communication highlights that users in CMC deliberately manage their appearance to carry out selective selfpresentation (Walther, 1996). The findings in this study support this model. Users selectively manage their performance by setting up their appearance and their surrounding environment. This kind of practice is supported by Olson's idea about appearance and self-presentation. Her essay explained how women manage their clothes for the sake of their selfpresentation. She stated that the clothes worn by women are intended to present their social status. It is assumed that their clothes are managed deliberately to show particular impression. Even so, this study finds that men are much more relaxed in setting their appearance. They find it is not necessary to manage their performance by choosing particular clothes when having VMC.

As it is found in this study, the existence of nonverbal cues in VMC does not eliminate users' effort to perform selective self-presentation. This happens when participants manage their appearance in VMC with a reason that they do not want their interlocutor to think anything bad about them. Although there is religious factor which also becomes the reason why they manage what they wear, however, their effort to do so is also conducted to maintain the personal image that they have built on offline world. In addition, users also want to be seen as persons who respect their interlocutor. Thus, there is users' effort to perform selective self-presentation in VMC. This is also related to users' confident who feel uncomfortable to show appearance without managing it, like DohertySneddon et al. examined in their study that VMC users' confidence is lower than FtF communication (Doherty-Sneddon et al., 1997).

Messages in the text-based CMC are created and interpreted based on the cognition ability of its users (Lea \& Spears, 1991), while it is different in VMC. Due to the presence of nonverbal cues, the users' ability to present and interpret messages depends on what they see on the available visual cues; even sometimes they need assistance from verbal explanation because of the limitation in accessing nonverbal signs in the VMC.

The result of this study shows a similar finding with research conducted by Wang, et al. (Wang et al., 2009) that Facebook users choose their best photograph before transmitting it. It also supports Walther's study (Walther, 2007) of a number of students who spend more time to arrange email sentences to create self-presentation. Making an appointment before having $\mathrm{VMC}$ provides more time 
for users to prepare and manage selfpresentation in VMC.

The finding also shows that users will perform selective self-presentation to ordinary friends and colleagues, in other words to people who are personally not close. However, this unlikely happens when they communicate to their closest people, such as family and close friends. Thus, users' selective self-presentation only applies to particular persons. So far, this research does not find any other studies which support this finding.

\section{Channel Characteristics and Nonverbal Cues Presence}

The purpose of this study is to examine whether online users perform selective self-presentation in a condition when nonverbal cues are presented and interlocutors are not anonymous. Although nonverbal cues are available in $\mathrm{VMC}$, still it has several limitations. Its inability to scan light changes in the visual signs or reach something which is unavailable in visual form such as odour becomes communication barriers. Nevertheless, this limitation is used by users as an opportunity to perform selective self-presentation.

The capability of VMC with its limitation of nonverbal display is able to hide users' surrounding from interlocutor. Hence, interlocutor is not able to access something that is deliberately hidden. This limitation does not decrease users' effort to perform selective selfpresentation. Finding discovered that users manage their presentation by showing good appearance and setting up their surrounding environment. Additionally, they also arrange where they will have the VMC. Yet, selective self-presentation which is built by users is not intended to present themselves as other. Turkle (Turkle, 1995) argued that online users can be anyone else on the Internet, but this is unlikely be applied in
VMC.

\section{CONCLUSION}

This study supports the results of previous studies on selective selfpresentation. First, users deliberately set themselves and their environment to form certain image to get desired impression from interlocutor. VMC users spend several times to organize themselves and their surroundings to get the desired impression that they want from interlocutor.

Second, this study finds that users also perform selective self-presentation in visual presence conditions to nonanonymous interlocutor. But this only applies to people who are not close to users and does not apply if the interlocutors are family or close friends. In VMC, users assume that they have to be looked as they are in real life when communicating with friends, colleagues, or acquaintances. Hence, the image that they have been building in offline world will be exactly the same in VMC.

\section{BIBLIOGRAPHY}

Bargh, J.A., Mckenna, K. Y. A., \& Fitzsimons, G. M. (2002). Can You See the Real Me ? Activation and Expression of the "True Self" on the Internet. Journal of Social Issues, 58(1), 33-48.

Doherty-Sneddon, G., Anderson, A., O'Malley, C., Langton, S., Garrod, S., \& Bruce, V. (1997). Face-to-face and VMC: A comparison of dialogue structure and task performance. Journal of Experimental Psychology: Applied, 3(2), 105-125.

Enrico, P., Bitti, R., \& Garotti, P. L. (2011). Nonverbal communication and cultural differences : issues for face-toface communication over the internet. In Face-to-Face Communication over the Internet (pp. 81-99). Cambridge: Cambridge University Press.

Goffman, E. (2008). The Presentation of Self in Everyday Life. In Sociology: 
Exploring the Architecture of Everyday Life Readings (7th ed.). Los Angeles: Pine Forge Press.

Heath, C., \& Luff, P. (1991). DISEMBODIED CONDUCT: COMMUNICATION THROUGH VIDEO IN A MULTIMEDIA OFFICE ENVIRONMENT. In Proceedings of the SIGCHI Conference on Human Factors in Computing Systems: Reaching Through Technology (pp. 99-103).

High, A. C., \& Caplan, S. E. (2009). Social anxiety and computer-mediated communication during initial interactions: Implications for the hyperpersonal perspective. Computers in Human Behavior, 25(2), 475-482.

Jiang, L. C., Bazarova, N. N., \& Hancock, J. T. (2011). The Disclosure Intimacy Link in Computer-Mediated Communication: An Attributional Extension of the Hyperpersonal Model. Human Communication Research, 37(1), 58-77. https://doi.org/10.1111/ j.1468-2958.2010.01393.x

Joinson, A. N. (2001). Self-disclosure in computer-mediated communication : The role of self-awareness and visual anonymity. European Journal of Social Psychology, 31, 177-192.

Kappas, A., \& Kraemer, N. C. (2011). Electronically mediated face-to-face communication: issues, question, and challenges. In Face-to-face Communication Over the Internet (pp. 1-13). Cambridge: Cambridge University Press.

Lea, M., \& Spears, R. (1991). Computermediated and group decision-making. International Journal of Man-Machine Studies, 34, 283-301.

McKenna, K. Y. A., \& Bargh, J. A. (1998). Coming out in the age of internet: Identity "de-marginalization" through virtual group participation. Journal of Personality and Social Psychology, 75, 681-694.

McKenna, K. Y. A., \& Bargh, J.A. (2000). Plan 9 from cyberspace: the implication of the internet for personality and social psychology. Personality and Social Psychology Review, 4, 57-75.

Mckenna, K. Y. A., Green, A. S., \& Gleason,
M. E. J. (2002). Relationship formation on the Internet: What's the big attraction? Journal of Social Issues, $58,9-31$.

Okdie, B. M., Guadagno, R. E., Bernieri, F. J., \& Geers, A. L. (2011). Getting to know you: Face-to-face versus online interactions. Computers in Human Behavior, 27, 153-159.

Parkinson, B., \& Lea, M. (2011). Videolinking emotions. In Face-to-face Communication Over the Internet (pp. 100-126). Cambridge: Cambridge University Press.

Poland, B. D. (2001). Transcription Quality. In Handbook of Interview Research: Context and Method (pp. 629-649). London: Sage.

Sellen, A. J. (1995). Remote conversations: The effects of mediating talk with technology. Human Computer Interaction, 10(4), 401-444.

Silverman, D. (2010). Doing Qualitative Research: A Practical Handbook (3rd ed.). London: Sage.

Silverman, D. (2011). Interpreting Qualitative Data (4th ed.). London: Sage.

Turkle, S. (1995). Life on the Screen: Identity in the Age of the Internet. London: Wedenfeld and Nicolson.

Walther, J. B. (1992). A longitudinal experiment on relational tone in computer-mediated and face to face interaction. In Proceeding of the Hawaii International Conference on System Science (pp. 220-231).

Walther, J. B. (1996). Computer-mediated communication: Impersonal, interpersonal and hyperpersonal interaction. Communication Research, 23, 3-43.

Walther, J. B. (2007). Selective selfpresentation in computer-mediated communication: Hyperpersonal dimensions of technology, language, and cognition. Computers in Human Behavior, 23, 2538-2557.

Walther, J. B. (2011). Visual cues in computer-mediated communication: sometimes less is more. In Face-toface Communication Over the Internet (pp. 17-38). Cambridge: Cambridge University Press. 
Walther, J. B., Slovacek, C., \& Tidwell, L. (2001). Is a picture worth a thousand words? Photographic images in long-term and short-term computer-mediated communication. Communication Research, 28, 105134.

Wang, S. S., Moon, S., Kwon, K. H., Evans, C. A., \& Stefanone, M. A. (2009). Computers in Human Behavior Face off : Implications of visual cues on initiating friendship on Facebook. COMPUTERS IN HUMAN BEHAVIOR, 26, 226-234. https://doi. org/10.1016/j.chb.2009.10.001

Wengraf, T. (2001). Qualitative Research Interviewing. London: Sage.

Whitty, M., \& Joinson, A. (2009). Truth, Lies and Trust on the Internet. East Sussex: Routledge. 